\title{
Implementation of Pluralist Education at Al- Azhar Mandiri Palu Junior High School
}

\author{
Suryani Lamsu 1*,Askar Askar 2, and Hamlan Hamlan³ \\ ${ }^{1}$ Islamic Education Department, Postgraduate, Institut Agama Islam Negeri Palu \\ 2 Islamic Education Department, Postgraduate, Institut Agama Islam Negeri Palu \\ ${ }^{3}$ Islamic Education Department, Postgraduate, Institut Agama Islam Negeri Palu
}

\begin{abstract}
This thesis examines the Implementation of Pluralist Education at SMP Al-Azhar Mandiri Palu. The school opens for learning opportunities for every student across religions, ethnicities, races and cultures. This school aims to educate all children of the nation, both Muslim and non-Muslim. The research used qualitative method with phenomenological approach. The data were collected through various instruments: observation, interviews and documentation. The sample are a non-Muslim Educator, seven Muslim educators, two Muslim students and six non-Muslim students. Based on the category, all samples played an active role in the application of pluralist education at Al-Azhar Mandiri Junior High School. This study found that pluralist education had been carried out since 1992, with a reference to the school motto of Smart and Moral. It motivates students to be smart but not being arrogant. Non-Muslim students remain in class when Islamic studies take place, and the teacher does not object. The application of Pluralist Education to the students is carried out in the form of growing tasamuh attitude (tolerance), building cooperation in group study and constructing a nondiscriminative action based on SARA as well as mutual respect between fellow students.
\end{abstract}

ARTICLE

INFORMATION 


\section{Introduction}

In Islamic history, respect for plurality has long been practiced. Prophet Muhammad SAW. Who manages the plurality of the people of Medina. Positive management of plurality has been able to reduce tensions and prolonged conflict between tribes in Medina, for example the successful cases of the Aus and Khazraj tribes. was reconciled by prophet Muhammad, through a treaty better known as the "Constitution of Medina", the relationship between the warring tribes in Medina was found to be a common point without harming the existence of each of the different groups. ${ }^{1}$

Plurality is a state of society (concerned in its social and political system), various different cultures in a society. The tradition of managing the spirit of plurality carried out by the Prophet Muhammad was later followed by his followers. As was done by the caliph Umar ibn Khattab who issued the "Aelia Charter" which regulates the order of public relations in Jerusalem.

Arnold added that the Christian minorities who lived in the cities during the first period of the Islamic Caliphate had enjoyed a full life of prosperity, because they received social security, in the form of; guarantees of safety of life and property as well as tolerance towards religious freedom. Arnold's appreciation is not something foreign to Indonesian Muslims, who in fact the

1Disadur dari Karlina, Pluralisme dan Inklusivisme Islam di Indonesia: ..., 14. majority adhere to the ideology of ahlSunnah wa Al-jama'ah (Aswaja), ${ }^{2}$ because that is the nature of Islamic law, in its social interactions, always adheres to the principles of moderation and tolerance, by prioritizing the benefit and interests of the public over personal or group interests.

More clearly, it can be seen in the writings of Abdurrahman Mas'ud, that religious tolerance has accommodated a process of exchange and assimilation that creates a unique color of Islam in the life of Javanese society. This mutual religious understanding has brought harmony as an important element in the religious life of the santri, namely the modified Sunni teachings that do not interfere with local traditions and customs.

At least the concept of harmony is associated with three elements, namely God, the individual, and the environment. This philosophy is believed to be able to realize a "peaceful coexistence" in a religious society, and of course in line with the Javanese philosophy which emphasizes unity, stability and harmony, this flexible pattern absorbs local and foreign elements, but still maintains Islamic principles. $^{3}$

Therefore, in the context of religious interaction and harmony, Islam teaches respect for every human being,

2 Ideologi Aswaja ini, dapat dibaca dalam Abdurrahman Mas'ud, Dari Haramaian Ke Nusantara: Jejak Intelektual Arsitek Pesantren, Cet. I (Jakarta: Kencana, 2006), h. 256-257.

${ }^{3}$ Abdurrahman Mas'ud, Dari Haramaian Ke Nusantara: Jejak Intelektual Arsitek Pesantren, Cet. I (Jakarta: Kencana, 2006), h. 256-257.

e-ISSN: 2715-4572

p-ISSN: 2716-1439 
including their religions and beliefs which may vary ${ }^{4}$. Islam Juga mengajarkan manusia untuk menjadi individu yang baik, menjadi tetangga yang baik, dan menjadi warga masyarakat yang baik, yang mengetahui hak-hak dan kewajibannya, serta memelihara kerukunan hidup diantara mereka.

Dialogue can occur between adherents of different religions, even lending and borrowing property exemplified by the Prophet Muhammad with followers of other religions. The principle held by Islam, in this case, is togetherness, justice, and peace among human beings. Thus, it is very reasonable if, in the context of Indonesianness, as Syafi'i Ma'arif said, the gold ink of history has also recorded how close and productive friendships have been created between Masjumi figures, with Catholic, Protestant leaders. And other religious leaders.

SMP Al-Azhar Mandiri Palu, is under the auspices of the Al-Azhar Mandiri Palu Foundation. According to Abdul Basit, this school is not an Islamic school, but it strengthens the religious beliefs of all students. SMP Al-Azhar Mandiri Palu wants to educate all the nation's children not only to Muslims because, according to Islam, doing good is not only for Muslims but also for humanity. ${ }^{5}$

The students of SMP Al-Azhar Mandiri Palu consist of various ethnic, ethnic, and religious backgrounds. The students in this school are not only those who are Muslim, but there are also some non-Muslim students. However, these non-Muslim students were so comfortable and excited to study at SMP Al-Azhar Mandiri Palu.

The diversity of cultural, ethnic, and religious backgrounds in this school shows that SMP Al-Azhar Mandiri Palu is implementing a pluralist education system which, according to its leader, this principle is part of the Islamic mission of rahmatan lil alamin. Precisely because of that, we chose the motto "Intelligent Moral." I understand the word rahmatan lil alamin, which means (to spread the love for the universe) is part of morals itself. ${ }^{6}$

SMP Al-Azhar Mandiri Palu was once a pilot school with international standards (RSBI), applying rules to disrespectfully expel students if they find their students involved as dealers or users of drugs and alcohol. This school is very consistent in upholding discipline in the teaching and learning process for
${ }^{4}$ Kurniati, Kurniati, Nurdin, Nurdin, \& Nurasmawati, Nurasmawati. (2020). Improving Students' Cognitive and Affective Domains Students through Fostering Teacher Development International Journal of Contemporary Islamic Education, 2(2), 56-70.

\begin{abstract}
the entire academic community and has
\end{abstract}
${ }^{5}$ Abdul Basit Arsyad (Kepala Sekolah SMP
dan SMA Al-Azhar Mandiri Palu, Wawancara ,
tanggal 17 Februari 2018.
${ }^{6}$ Abdul Basit Arsyad, Wawancara, tanggal
17 Februari 2018. di SMP Al-azhar mandiri Palu
e-ISSN: $2715-4572$
p-ISSN: $2716-1439$ 
a competitive level of graduate competition both locally and nationally. ${ }^{7}$

That is why the author chose SMP Al-Azhar Mandiri Palu as the object of research, not only because SMP AlAzhar Mandiri Palu has become a favorite school for the people of Palu and Central Sulawesi, but also because in the author's observations, there were 15 non-Muslim students. Who is currently studying at SMP Al-Azhar Mandiri Palu. Meanwhile, in Palu City, there are schools with Christian characteristics, such as Gamaleal Junior High School in Maesa Village and Catholic Junior High School in Kamonji Village, and Karunadipa Junior High School in Nunu Village, where the majority of students are Hindu and Buddhist Christians.

\section{Literature review}

\subsection{Development of a Culture of Plurality}

In Max Dimont's view, Islam came as a gift that brought peace and religion that always invites to always do good, ending the tyranny of Spain's Christian rulers. For 500 years, Islam created a Spanish State for three religions: Islam, Christianity, and Judaism in "one bed." The Muslims, Christians, and Jews of Spain lived in harmony and together built a great civilization and set an impressive example. The existence of such religious harmony does not result in religious

\footnotetext{
${ }^{7}$ Arafat Arsyad (Guru Pembina SMP AlAzhar Mandiri Palu), Wawancara, tanggal 17 Februari 2018.di SMP Al-Azhar mandiri Palu
}

unification because most of the people of Spain remain Christian and they continue to live in harmony. ${ }^{8}$ Islam is increasingly expected to come up with productive and constructive cultural offerings and claim itself as a carrier of goodness for all, without communal exclusivity. Is there a portrait like that happening among the Muslims of the 21st century?

After the bombing that destroyed the twin buildings of the World Trade Center (WTC) Washington on September 11, 2001, with the alleged perpetrator being the al-Qaeda group, the image of the adherents and teachings of Islam was increasingly negatively portrayed by the Western media. This image then tends to expand the arising of Western suspicion towards Muslims and the religion of Islam. ${ }^{9}$

With the end of the cold war marked by the collapse of the Eastern Bloc led by the Soviet Union, the West then defeated suspicions about its old rival, Islam. There are various reasons to justify this suspicion. The existence of repressive totalitarian regimes in the Arab world and other Islamic countries, the occurrence of the gulf war, the suicide bombing of Palestinians, the terror incidents in Indonesia, which culminated in the bombing incident in Legian, Bali, further raised this suspicion. In the end, this kind of thing

\footnotetext{
8 Lihat Nurcholish Madjid, Islam Doktrin dan Peradaban, (Jakarta: Yayasan Wakaf Paramadina, 2000), h. 161.

9 Azyumardi Azra, Konflik Baru Antar Peradaban Globalisasi, Radikalisme dan Pluralitas, (Jakarta: PT.Grafindo Persada, 2002), h. 14.

e-ISSN: $2715-4572$

p-ISSN: 2716-1439
} 
grows suspicious of the West towards Islam.

On the other hand, the influence of Western media propaganda about the threat of terrorism from the Islamic world and the perception that the emergence of militant groups and terrorists originating from Muslims further strengthens the negative stigma of the West. Muslims are considered difficult to respect and recognize plurality. Islam is identified with a culture of violence and terror. The Western world has often linked the source of violence with Islam even though the violence occurs everywhere, in various parts of the world, and involves followers of various religions.

The departure of the Western world in seeing the Muslim world negatively has further obscured the problem. It is like "extinguishing a fire" and not looking for the source of the fire by preventing it when the source of the fire is still small, that the emergence of violence comes from the existence of injustice and inequality in the order of international relations. America's policy to support and protect Israel in its conflict with Palestine is one of the triggers for the displeasure of the Muslim community. Coupled with an arbitrary attitude and without UN approval, America and its allies, Britain and Australia, invaded Iraq. This adds a negative image to both America and the West. In many ways, they always claim to be loyal supporters of democracy and human rights, but they are "two-faced" in reality. Acting arbitrarily and violating human rights without a UN mandate.
This unfair pattern of international relations can eventually become an institutionalized memory in the minds of Islamic society and the third world towards the West. As a result, efforts to build good relations among the world's population by prioritizing peace and rejecting all forms of violence are meaningless. In the end, this will not be able to stem the flow of global tensions. In fact, there is a tendency to continue to be suspicious of one another. ${ }^{10}$ Thus, the emergence of this tension is more based on the existence of global injustice.

Responding to this, for Muslims, in order to reduce the existence of this tension, is to return to the understanding of their religious doctrine by motivating themselves to do their best for world peace. Remembering that this is the recommendation of the Koran to compete with each other in goodness.

For Muslims, it is necessary to know that the face of Islam, which is inclusive and respects plurality, has brought Islam to the front gate of its glory. Islam was once able to mediate between religious communities, namely when Islam highly valued non-Muslim minorities in its golden age between the 5th and 12th centuries AD, where Muslims invited followers of other religions such as Christianity and Jews to sit together in government and develop knowledge together. This attitude of inclusivism then became the principle of the heyday of Islam and has

10 Lihat Egi Sudjana, Politik Kekerasan dan Terorisme Negara, (Bogor: Yayasan Assahidah, 2002), h. 32. 
based political policy on religious freedom.

But what is happening nowadays with the rampant acts of violence under the pretext of religion? Is there any hope for a tolerant Islam in the midst of the Muslim community? For example, various tragedies at the international and local level, for example, the suicide bombing involving a family in several non-Muslim places of worship that occurred in Surabaya, opened our eyes to the real threat of an exclusive religious pattern that rejects diversity because it feels like it has a monopoly on the truth. The anti-pluralist character of this group raises the view of takfir, which is to disbelieve other people or groups who have different opinions from them and to justify violence for religious propagation.

It is better if we have to return our memories to the ideal Islamic concept, which is based on the spirit of humanity and the universality of Islam. The theological understanding of Islamic universality can be traced from the alignment of al-Islam itself, which means submission to God or peace.

Based on this understanding, all true religions must be al-Islam because they teach submission to God and peace. Interpretation like this will lead to the concept of prophetic unity and the unity of humanity. These two concepts are (the unity of God or tauhid). All these conceptions make Islam cosmopolitan and capable of being a blessing for all nature. This position requires Muslims to become mediators (ummatan wasatan) and witnesses (martyrs) among human beings. However, the ideal concept is not in line with what is understood by certain Islamic groups. They still behave in an exclusive and fanatical way in seeing religion. Though often fanaticism can lead and make people seek sensation and overcompensation.

In one of Jalaluddin Rumi's verses, it is stated: "Even though there are various religions, the goal is one. Don't you know that many roads are leading to the Ka'bah? Therefore if what you are considering is the way. Very diverse and unlimited in number. But when what you stretch out is the goal, everything is only focused on one goal." 11

Normatively, every religion carries a mission as a carrier of peace and harmony in life. Not only among humans but also among God's creatures in this universe. In the terminology of the Qur'an, this sacred mission is called rahmatan lil alamin (mercy, peace for the universe). The holy mission was proven true and real by the Prophet Muhammad. During his leadership, he was always consistent in carrying out a peaceful mission to become a blessing for all nature.

\subsection{Plurality-Based Islamic Religious Education}

From the awareness of the phenomenon that "one God, many religions" is a fact and reality faced by humankind from ancient times until now. So, now there must push for humans towards the awareness that plurality is indeed the nature of human

11 Karlina, Pluralisme dan Inklusivisme Islam di Indonesia: ..., h. 21. 
life. The community is also required to be able to develop mutual respect between members of the community by respecting what is considered the most important for each person and group. Encouraging everyone to appreciate "diversity" is an important and immediate effort in Indonesia, especially in the educational environment, especially in Palu City, Central Sulawesi Province.

It is important to note that this area, especially in Poso District $(450 \mathrm{~km}$ from Palu City), has been plagued by horizontal conflicts for a long time and has seriously harmed the structure of community life. The impact of the multidimensional conflict and crisis that hit Indonesia has caused this nation to face various social problems. One of the big problems where the role of religion is very questionable is ethnic, cultural, and religious conflicts or better known as SARA.

The failure of religion to play its role as a problem solver for SARA problems is closely related to religious teaching exclusively. So, in order to get out of the crisis that plagued the Indonesian nation regarding the issue of SARA, it is time for the Indonesian nation to bring up the face of pluralist and tolerant religious education.

The Indonesian people have long been familiar with the motto Unity in Diversity. But unfortunately, this concept has undergone a twisted meaning and interpretation bias, especially during the New Order government. At that time, the sociopolitical policies tended to be uniformistic, so it seemed that the culture belonging to the dominant group was taught and transmitted by schools from one generation to another.

At that time, it is also suspected that schools only reflected and echoed stereotypes and prejudices between groups that had been formed and circulated in society, not trying to neutralize and eliminate them. There are indications that schools develop prejudice and escalate tensions between groups through legislation that divides the delivery of religious education, ethnocentric curriculum content, and the dynamics of social relations between schools that are segregated. ${ }^{12}$ It is not impossible that school segregation based on religious adherence will also exacerbate prejudice and the process of domination between one group and another, either directly or indirectly.

In fact, according to $S$. Hamid Hasan, "the diversity of social, cultural, economic and political aspirations, and economic capacity is a reality of the people of the Indonesian nation. However, the diversity of social, cultural, economic, and political aspirations that should be taken into account in determining philosophy, theory, vision, document development, curriculum socialization, and curriculum implementation does not appear to be a factor that should be a must consider in the implementation of the educational

12 Khisbiyah, Yayah (at al.,) "Mencari Pendidikan Yang Menghargai Pluralisme" dalam Membangun Masa Depan Anak-anak Kita, (Yogyakarta: Kanisius, 2000), h. 156-157. 
curriculum in education. Our country". ${ }^{13}$ So, as a result, it is natural when there is a failure in education (including religious education), especially in fostering attitudes to mutual respect for differences in society.

In addition, according to Azhar Kausar Noer, ${ }^{14}$ Mentioned, at least four factors cause the failure of religious education in fostering pluralist attitudes. First, in the learning process, the emphasis is more on the process of transferring religious knowledge rather than on the process of transforming religious and moral values to students; second, the attitude that religious education is nothing more than a mere "curriculum decoration," or as an underestimated "complement"; third, the lack of emphasis on cultivating moral values that support interreligious harmony, such as love, compassion, friendship, being helpful, peace-loving and tolerant; and fourth, the lack of attention paid to studying other religions. ${ }^{15}$

13 S. Hamid Hasan, "Pendekatan Multikultural Untuk Penyempurnaan Kurikulum Nasional", dalam Jurnal Pendidikan dan Kebudayaan, (Jakarta, Edisi Bulan JanuariNovember, 2000), h. 510-511.

14 Azhar Kausar Noer dalam Sumartana (at al), Pluralisme, Konflik, dan Pendidikan Agama di Indonesia, (Yogyakarta: Pustaka Pelajar, 2001), h. 239-240.

15 Evita, E., Syahid, A., \& Nurdin, N. (2019). Understanding Students' Learning Outcomes Differences Through the Application of the Market Place Activity Type of Cooperative Learning Model and the Application of Conventional Learning Models International Journal of Contemporary Islamic Education, 1(1), 6785.
Seeing this reality, even coupled with the many conflicts, violence, and even cruelty that are carried out in the name of religion, as mentioned above, it should be the purpose of reflection on religious education to be able to transform religious life itself by looking at the divine and social Culture. Religious education must be able to instill a better and more polite way of life in students. So that attitudes such as mutual respect, sincerity and tolerance of religious and cultural diversity can be achieved in the midst of a plural society.

By realizing that our society consists of many tribes and several religions, it becomes very pluralist. Thus, the search for alternative forms of education is necessary. It is a form of education that seeks to preserve the culture of a society and transfer it to the next generation, foster values, foster friendship between students of various ethnicities, races and religions, develop educational attitudes like this that many "experts" offer in the context of anticipating religious conflict and towards lasting peace, which has become known as "pluralist education." Plurality is a measure of human progress when he accepts other people and coexists with him, and when he is ripe, he will see the elements and characteristics of morals as well as the factors and characteristics of unity and similarity.

What exactly is pluralist education? If we trace references to pluralist education, there is a lot of literature on that education or what people often know as "multicultural education." More clearly, it is interesting if we pay e-ISSN: $2715-4572$ p-ISSN: 2716-1439 
attention to a definition of pluralist education conveyed by Frans Magnez Suseno, which is an education that presupposes us to open a vision to a wider horizon, able to cross the boundaries of our ethnic groups or cultural and religious traditions so that we are able to see "humanity. "As a family that has both differences and similarities in ideals. This is education on basic human values for peace, independence, and solidarity.

Ainurrofiq, Explained the definition of multicultural education as a process of developing all human potential that respects its plurality and heterogeneity as a consequence of the diversity of ethnic, ethnic, and religious (religious) cultures. This definition of multicultural education, of course, has very broad implications in education because education itself is generally understood as an endless process or a lifelong process. ${ }^{16}$

The ideas and concepts of education that consider plurality aspects (multiculturalism), according to Azyumardi Azra, can be said to be quite sensitive in certain aspects, especially considering that there was a very sharp controversy before the enactment of Law No. Article 12 paragraph 1 point a reads: "Every student in each educational unit has the right: to receive religious education in accordance with his / her religion and is taught by educators of the same religion." This controversy about religious education occurs when Muslims, on the one hand, support

16Dawam, Ainurrofiq, Emoh Sekolah, (Yogyakarta: Inspeal Ahimsa Karya Press, 2003),h. religious education with the same religious teachers, but Christians, on the other hand, reject it. Now the controversy is no longer heard, but according to Azra, this problem is still like "embers in the husk," which can burn at any time. ${ }^{17}$

It is important to note that every cultural, ethnic, religious, and community can affirm its existence and can participate actively in fulfilling the necessity of living together with equality. Will Kymlica, in Multicultural Citizenship, said that currently, multiculturalism had become an inseparable part of the development of modern society. Multiculturalism as a reality in modern society arises due to cultural and ethnic diversity. Multiculturalism has become a social movement and a political identity movement to fight for people's lives. ${ }^{18}$

In fact, Law No. 20 on the National Education System has described the principles and perspectives of multicultural education. In principle, this provision has two specific objectives: first, to guard against deviations or misinterpretations of religious norms that can occur if taught by educators who are not of the same religion; second, with teachers who are of the same religion as students, religious harmony can be maintained

17Lihat Azyumardi Azra, Dari Harvard Hingga Makkah, (Jakarta: Republika, 2005), h.150.

18 Dody S.Truna, Pendidikan Agama Islam berwawasan Multikulturalisme Telaah Kritis atas Muatan Pendidikan Multikulturalisme dalam Buku Ajar Pendidikan Agama Islam (PAI) di Perguruan Tinggi Umum di Indonesia (Jakarta: Kementerian Agama RI, 2010), h. 16.

e-ISSN: 2715-4572

p-ISSN: 2716-1439 
between students of different religions studying in the same educational unit; and third, to ensure professionalism in the implementation of the learning process and religious education.

Thus, multicultural education requires the highest respect and respect for human dignity, wherever he comes from and whatever culture. The hope, at a glance, is the creation of true peace, security that is not haunted by anxiety, welfare that is not haunted by manipulation, and happiness that is separated from the web of social engineering manipulation.

Developing a pluralist attitude towards students in the current era is absolutely "done" by all religious education in Indonesia for the sake of true peace. Islamic religious education needs to immediately present tolerant Islamic teachings through its educational curriculum with the aim and emphasis on understanding and efforts to live in the context of religious and cultural differences, both individually and collectively, and not to be trapped in primordialism and exclusivity of religious and cultural groups. The narrow. So that these plural attitudes will be developed in our young generation through the dimensions of religious education by paying attention to matters such as the following:

Religious education such as fiqh, interpretation does not have to be linear, but uses the muqaron approach. This becomes very important because children are not only provided with knowledge or understanding of legal provisions in fiqh or the meaning of a single verse but also given different views. Of course, it is not just knowing what is different but also knowing why it is different.

In developing social intelligence, students must also be given interfaith education. This can be done through interfaith dialogue programs that need to be organized by Islamic educational institutions. For example, a dialogue on "fasting" which could present bikhsu or religious leaders from other religions. This program is very strategic, especially to give students an understanding that fasting is also teaching our Buddhist brothers. With dialogue like this, students are expected to have an understanding, especially in assessing the beliefs of our brothers of different religions. Because in fact, "Outside Islam There is Salvation."

A Mukti Ali, an expert on comparative religions, although he does not explicitly state his idea as a theory of religious pluralism, he explains five 'paths' that can be taken by religious communities to realize peace and harmony in a pluralistic and pluralistic reality. ${ }^{19}$ :

\section{Methodology}

This study uses a qualitative approach with the object of research is a high school in Palu. In this study, the writer took one of the high schools to be the case.

19 Mukti Ali, Kuliah Agama Islam di Sekolah Staf dan Komando Angkatan Udara Lembang (Yogyakarta: Yayasan Nida, 1973), h. 17-24 yang dikutip oleh Faisal Islmail, "Islam, Pluralisme dan Kerukunan Hidup Antar Umat Beragama di Indonesia" dalam jurnal Unisia, No. 33/XVIII/I/1997, h. 61-63. 
Use qualitative methods in this study with several considerations. First, adjusting qualitative methods is easier when dealing with multiple realities. Second, it can directly present the nature of the relationship between researchers and informants 20 . Third, this method is more sensitive and adaptable to the many sharpening of the common direction and the patterns of values encountered. 21

Based on the results of the visit, field observations, and interviews with school principals and teachers in SMA Al-Azhar Palu, the chosen subjects for the study of pluralism was prominent.

Data were collected using observation techniques, in-depth interviews, and studies from shared written documents. ${ }^{22}$ While the data analysis is done using reduction and verification techniques with various data sources. $^{23}$ The reduced data is then

${ }^{20}$.Nurdin, Nurdin, Stockdale, Rosemary, \& Scheepers, Helana. (2014a). Coordination and Cooperation in E-Government: An Indonesian Local E-Government Case The Electronic Journal of Information Systems in developing Countries, 61(3), 1-21.

${ }^{21}$ Nurdin, Nurdin. (2018). Institutional Arrangements in E-Government Implementation and Use: A Case Study From Indonesian Local Government. International Journal of Electronic Government Research (IJEGR), 14(2), 44-63. doi: 10.4018/ijegr.2018040104

${ }^{22}$.Nurdin, Nurdin, Stockdale, Rosemary, \& Scheepers, Helana. (2014b, 6-9 Jan. 2014). The Role of Social Actors in the Sustainability of EGovernment Implementation and Use: Experience from Indonesian Regencies. Paper presented at the System Sciences (HICSS), 2014 47th Hawaii International Conference on System Science.

23 Nurdin, Nurdin, \& Aratusa, Zana Chobita. (2020). Benchmarking level interactivity of Indonesia government university websites. analyzed by claiming to the theoretical concepts used in this study.

\section{Result and Discussion}

\subsection{Application of Pluralist Education}

Some of the efforts made to accustom plurality to the character of students at SMP Al-Azhar Mandiri Palu were inspired by the motto of Intelligent Moral, which is to always motivate students to have intelligence not only from an academic side but also emotional intelligence and spiritual quetions that can be a role model. Role models both in the school environment and in the community.

According to Abdul Basit, AlAzhar's Motto, which is Intelligent Moral, is a characteristic of Islam Rahmatan Lil Alamin. ${ }^{24}$ Basit understands that morals and morals are one of the fundamental aspects of the characteristics of Islam Rahmatan lil Alamin. Therefore, to add and strengthen insight into Islamic knowledge for Al-Azhar students, we are not only tied to learning Islamic religious education according to the curriculum, but are strengthened by additional programs such as; Ramadan Islamic boarding schools, Islamic boarding schools, reading and memorizing the Al-Qur'an, and participating in various Islamic activity competitions.

TELKOMNIKA Telecommunication, Computing, Electronics and Control, 18(2), 853-859.

${ }^{24}$ Abdul Basit Arsyad, Kepala Sekolah SMP
Al-Azhar Mandiri Palu, Wawancara, tanggal 17
Februari 2018.di SMP Al-Azhar mandiri Palu
e-ISSN: 2715-4572
p-ISSN: 2716-1439 
Basit is right by offering a variety of alternative activities with religiosity, equality in daily interactions, and to shape the moral. Moral intelligence of Al-Azhar Mandiri Junior High School students because religious education has the largest share in shaping the character of students.

Thomas Lickona, as quoted by Nurhayati Djamas, describes the positive character components, as in the Santrock concept, which also includes three components, namely moral knowing, moral feeling, and moral action. ${ }^{25}$ States: religious education can be linked to the three moral components that are pillars of positive character, which include moral knowledge, or cognitive aspects, moral feeling, and moral action, which refers to the values of religious teachings. ${ }^{26}$

\subsection{Cooperation in study groups and social action.}

Meanwhile, the method taken to form a plurality of insights from SMP Al-Azhar Mandiri Palu students is to form a conscious effort to make improvements and uphold the values of difference as something that is complementary so that students are able to understand that the life of diversity is

\footnotetext{
25 Lihat Nurhayati Djamas, "Pembinaan Mental Spiritual Anak Dalam Kehidupan Bermasyarakat", makalah disampaikan dalam Lokakarya Pengembangan Kemampuan Hakim "Membangun Komitmen Bersama Dalam Rangka Meningkatkan Kemampuan Hakim Terhadap Keadilan dan Perlindungan Anak", diselenggarakan oleh Komisi Yudisial Republik Indonesia, Bandung, 2010b, h. 3.

${ }^{26}$ Lihat, Nurhayati Djamas, Memfungsikan Pendidikan Agama Sebagai Pendidikan Karakter Pada Anak, dalam Jurnal Alumni UIN, BIJAK . Volume 5 , Nomor 1, 2017,... h. 151.
}

very important. Besides always inviting students together to carry out positive socio-religious activities and actions without distinguishing ethnicity, religion, race, customs, and culture.

Meanwhile, the method taken to form a plurality of insights from SMP Al-Azhar Mandiri Palu students is to form a conscious effort to make improvements and uphold the values of difference as something that is complementary so that students are able to understand that the life of diversity is very important. Besides always inviting students together to carry out positive socio-religious activities and actions without distinguishing ethnicity, religion, race, customs, and culture.

Suppose the learning process of the Islamic Religious Education subject is taking place both in the form of learning in class and in the form of reciting (reading and writing) the Koran. In that case, non-Muslim students will still be present in class and present at the Musalla when reading the Al-Qur'an. in progress (see photo in attachment). This can also be seen in the implementation of Islamic Holidays (PHBI) activities at Al-Azhar Mandiri Junior High School in Palu.

The implementation of Islamic religious activities also involves nonMuslim students, especially in the ceremonial field. This phenomenon has taken place several years ago, and the student's guardian approved the involvement of non-Muslim students. This attitude of togetherness also comes from the religious views of the founder of the Al-Azhar Foundation, Ustadz Rustam Arsyad. 
Ustaz Rustam is also known to be very moderate and tolerant of nonMuslims as far as muamalah issues are concerned. In 1982-1993 (11 years) he raised a Hindu child named I-Nenga Suleman from Bali as a transmigrant in Buranga Ampibabo, Donggala Regency (now Parigi Moutong). I-Nenga attended GPID then continued to STM. After graduating from STM, he passed the apprenticeship selection test to Japan for two years (1991-1993). Upon his return from Japan, he was able to live independently.

He said farewell to Ustad Rustam's family to live alone and open a motorbike repair shop. Even though he doesn't live at home anymore, when he has a need, he often says goodbye to Ustazd Rustam's family, so that until now, his relationship is still good even though he is still a Hindu. Likewise, when he was still in the sewing business at Jl. Gajah Mada Palu, is a neighbor of several Chinese people; Hope Coffee Shop (Acknowledge), Lakama, Miliong. ${ }^{27}$ They live as neighbors like a family in harmony and peace.

The moderate and tolerant attitude displayed by Ustadz Rustam as a teacher of the Al-Azhar Foundation is undeniably thought to have come from the results of the upbringing and guidance of his teacher, Habib Idrus bin Salim Aljufri or usually called Guru Tua at the Alkhairaat madrasah. When it was first established, the Alkhairaat madrasa appeared as a balancing force for Christianization in their respective

27 Lihat Gani Jumat, Laporan Penelitian LP2M IAIN Palu 2018 regions, but the Alkhairaat's role did not prevent Guru Tua from continuing to build communication with pastors and Christians. The following quotes are historical facts in Palu City.

Guru Tua not only shows tolerance at the conceptual level but also provides a concrete example by appointing a young pastor named Pena Tua P.K. Entoh (late), as a teacher of al-Jabar science (trade arithmetic) at the Alkhairaat Islamic Boarding School in 1955-1960. P.K. Either tell his memories with the Guru Tua while teaching. P.K. Either teaches at Alkhairaat at Muallimin and M.L.P (First Advanced Madrasah) every Saturday and Sunday, after finishing church services around 11.00. The person who invited P.K. Either Ustadz Mahfud Godal and Abbas Palimuri on the orders of the Guru Tua. At that time, P.K. For whatever reason, how could I teach at Alkhairaat when I was a Christian. The reason was conveyed to the Guru Tua, so Guru Tua answered that knowledge was needed, not religion. P.K. So for five years, PK Entoh taught at Alkhairaat, and in mid1960, PK Entoh stopped teaching at Alkhairaat because he was assigned to study in Makassar.

P.K. Either, one of the pastors, said that Guru Tua had followed a professional recruitment pattern according to the academic qualifications of each individual in certain scientific fields. If we look at the pastor's year of dedication, it coincides with a period of political "rioting" or rebellion from separatist movements, such as Permesta, DI / TII. The condition of harmony between religious communities in e-ISSN: $2715-4572$ p-ISSN: 2716-1439 
Indonesia is still quite prone to say that it is full of tensions, as a result of the differences in views between Islamic nationalist political forces and "secular" nationalists in determining the shape and ideology of the state in the case of the Jakarta Charter. ${ }^{28}$

What was shown by the Guru Tua, who later passed on by Ustadz Rustam, is something extraordinary. It can even be said to be a form of tolerance (tasamuh) that transcends its time. It is said to have transcended its era because, in the 1950s, the Indonesian state itself was in the context of new tolerance, which was limited to the discourse of verbal discourse, there was no real action in the daily life of the community, but Guru Tua and his students had set an example at the Alkhairaat madrasa. Ustadz Rustam later adopted the attitude and actions of Guru Tua by taking care of a Hindu child, I-Nenga, in his house, as quoted above.

Tolerance is often used to accommodate different interests from the point of view of ethnicity, race and religion. Because the problem of tolerance itself is born from a relationship that is directly related to race and religion. Namely when there is racial discrimination in certain communities, and it has been going on for a long time. Examples that we can still remember are the incidents of opposing white people against black people, Israel against Palestine, Serbia against Bosnian Muslims, and so on. In

28 Lihat, Tim Penulis, Huzaemah T.Yanggo dan Gani Jumat, (at.al). Sayyid Idrus Bin Salim Aljufri Pendiri Alkhairaat,... 118. Lihat juga, Gani Jumat, Nasionalisme Ulama,...h. 105.
Indonesia, it has been treated to Chinese ethnic groups, and even this view is still ongoing today.

There are two types of interpretation regarding the concept of tolerance. The first opinion says that tolerance only means that other people are allowed to do something or are not disturbed (negative understanding of tolerance). The second opinion says that tolerance requires more than that, which requires assistance, assistance, and guidance (a positive understanding of tolerance). However, this positive understanding of tolerance is only needed in one situation where the goal of tolerance is something that is morally immutable and irreversible, as in the case of racial tolerance.

Tolerance can also mean an attitude of mutual respect and respect between groups or individuals either in society or in other spheres. An attitude of tolerance can avoid discrimination, even though there are many different groups or groups in a community group. In addition, tolerance is not only related to legislation but also social attitudes. Today there is little discrimination and intolerant behavior towards such legislation. However, intolerance among individuals or groups still appears in many cases, whether as a result of motivations from race, ideology, political rules, or religion.

To minimize the existence of religious discrimination, the Indonesian government has implemented a Trilogy policy of religious harmony as a first step towards forming that tolerance. The trilogy states: first: tolerance among adherents of a particular religion. e-ISSN: 2715-4572 p-ISSN: 2716-1439 
Second: tolerance between adherents of different religions. And the third is tolerance between religious followers and the government. The foundation of the trilogy of religion harmony with the government. The foundation of this trilogy of religious harmony is, of course, born from the awareness of the plurality of religions in Indonesia. ${ }^{29}$

In addition, the recommendation for tolerance is in line with the teachings of the Al-Qur'an to carry out dialogue and not to commit violence against other religions and to the people of the book.

Thus, cultural pluralism, as a result of differences in ethnicity and religious beliefs, does not automatically lead to disputes, antagonisms, conflicts, and disintegration. Pluralism or multiculturalism also creates unity and strengthens cooperation and unity because pluralism gives richness to the character of the nation. At the same time, we need to understand what is meant by the word "unite," an entity that is constantly being challenged by the existing plurality of phenomena.

\subsection{Unite in the Arts and Sports Club}

If you look at the various types of charters and trophies displayed in AlAzhar Mandiri Palu Middle School's archives and documentation cabinets, both city-level, regional, national, and international-level achievements, it will show that this school really has extraordinary achievements when compared to other junior high schools.

29 Gani Jumat, KH.Rustam Arsyad: Ulama Penyebar Islam Moderat Di Sulawesi Tengah (Laporan Penelitian LP2M IAIN Palu, 2017), h. 30-31.
For example, the Volleyball group, the Basketball group, the Takrau football group, and others. This Sports Group involves a plurality of ethnicities, religions, races, and different cultural orientations. However, there is very strong cooperation and solidarity. Solidarity, getting to know each other, and cooperation are reflected in the many achievements made by students of SMP Al-Azhar Mandiri Palu.

The implementation of pluralist education has a major role in developing students into human beings who have noble morals, have awareness, and hope to increase their potential in a positive direction. Therefore, to foster awareness of the plurality of students in the school environment, in addition to the methods mentioned above, as educators, they must be creative in fostering the basic interest and potential of students and their awareness of the importance of understanding the reality of the diversity of life in the school environment even though they are not subject educators. Islam.

According to Amin Abdullah: He suggested "the need for the reconstruction of socio-religious education to reinforce the dimension of the socio-religious contract in religious education." In this case, if so far practiced in the field, Islamic religious education still emphasizes the safety side that is owned and desired by others outside of themselves and their own groups - so religious education materials are more focused and busy taking care 
of their own affairs (individual or private affairs.). ${ }^{30}$

So, according to Amin Abdullah, Islamic religious education needs to be reconstructed so that it emphasizes more on the social education process, not merely individually, and to introduce the concept of a social contract. So that students are implanted in a belief that from the start we all differ in many ways, especially in the fields of faith, faith, creed, but in order to maintain harmony, safety, and the interests of life together, like it or not, we must be willing to establish cooperation (cooperation) in the form of a social contract between fellow groups of citizens. ${ }^{31}$

In order for the aims and objectives of plurality-based Islamic religious education to be achieved, the curriculum must be designed in such a way and is favorable for all levels and levels of education. However, at the primary and secondary school level, it is the most important because, at this level, the attitudes and behavior of students are still ready to be formed. And it should be noted. A curriculum cannot be implemented without direct involvement, creation, and collaboration between curriculum makers, textbook writers, and teachers.

In fact, all subjects must instill these values so that they are woven and engraved in the minds of students that appreciating a difference is a good thing.

30 M.Amin Abdullah, Studi Agama: Normativitas atau Historisitas, (Yogyakarta: Pustaka Pelajar, 1999), h. 76.

31 M.Amin Abdullah, Studi Agama,... h. 76.
Educators must be able to teach mutual respect of differences by telling stories that remind them of how this nation was built, fought over ethnic, religious, and racial diversity but still has a determination to build the Indonesian nation as referred to in the motto of Bhineka Tunggal Ika. Different but still one.

Unity comes from the Latin unitas, which actually means unicitas. Unicitas is the same in Indonesian as "unity," which denotes complete integrity. However, it needs to be realized that the Indonesian nation is currently aiming at this unity and integrity. The existing tensions and conflicts are expected to be a continuous process towards fuller integration. The forms of unity implemented in the AlAzhar Junior High School as described above cannot be denied that they can become a pillar for upholding Indonesian national unity as a whole.

The facts to date show all school levels at the Al-Azhar Mandiri Palu Foundation, starting from the SD, SMP, and SMA Al-Azhar Mandiri Palu levels which are under the auspices of the AlAzhar Mandiri Palu Foundation. What we see now is a blueprint or charity. Jariyah, which is very useful which has been pioneered by the founders of KH.Rustam Arsyad and continued by his successors. The diversity of cultural, ethnic, ethnic, and religious backgrounds in the SMP Al-Azhar Mandiri Palu school, as well as the use of the motto "Intelligent in character," shows the expression of the style and religious style of its founder, namely Moderate Islam-Islam Rahmatan Lil e-ISSN: 2715-4572 p-ISSN: 2716-1439 
Alamin, which means dear to the universe).

Thus, what has been initiated by the founder of Al-Azhar, Ustadz Rustam Arsyad, which was then continued by the next generation of Abdul Basit Arsyad, has proven that a vision and mission as a lofty ideal has been implemented in such a way in the real form of Junior High Schools. AlAzhar Mandiri Palu, which applies a pluralist-minded education style.

\section{Conclusion}

Based on the results of the research that has been done, the writer concludes that pluralist education for students of SMP Al-Azhar Mandiri Palu has been carried out long ago by referring to the motto of Intelligent Character. Motivate students to be smart but not arrogant. Non-Muslim students remain in the class when Islamic Religion lessons take place, and the guardians of students do not object to this situation. In addition, the student self-development model through group work orientation is also applied. If there is a group assignment, it is done jointly between Muslim and non-Muslim students in one group, and if there are Muslim students' activities, then nonMuslims will also attend the class without being disturbed. Likewise, the RPP for the subject of Religion and character education at SMP Al-Azhar Mandiri Palu is integrated with pluralist education.

\section{REFERENCES}

Abdillah, Masykuri (et.all). BayangBayang Fanatisisme-Esai-esai Untuk Mengenang Nurcholish Madjid, Cetakan I (Jakarta: Paramadina, 2007).

Abduh, M.Rifa'i dan Rafael Edi Bosko. "Kebebasan Beragama Atau

Berkeyakinan: Seberapa Jauh? Sebuah Referensi Tentang PirnsipPrinsip dan Praktek", Diterbitkan pertama kali oleh the Oslo Coalition on Freedom of Religion or Believe dalam rangka memperingati 20 tahun Deklarasi tentang Penghapusan Segala Bentuk Diskriminasi (Yogyakarta: Kanisius, 2010).

Abdun, Abdullah. Al-Khairaat wa Muassisuha,

Abdurrahman Mas'ud, Dari Haramaian Ke Nusantara: Jejak Intelektual Arsitek Pesantren, Cet. I (Jakarta: Kencana, 2006)

Ahmad Syafi'i Ma'arif, Sekapur Sirih, dalam W.Cole Durham Jr., Bahia G. Tahzib-Lie, (Editor). Facilitating Freedom of Religion or Believe: A Deskbook, Tore Lindholm, Terjemahan, Rafael Edi Bosko dan M.Rifa'i Abduh, "Kebebasan Beragama Atau Berkeyakinan: Seberapa Jauh? Sebuah Referensi Tentang Pirnsip-Prinsip dan Praktek", Diterbitkan pertama kali oleh the Oslo Coalition on Freedom of Religion or Believe dalam e-ISSN: 2715-4572 p-ISSN: 2716-1439 
rangka memperingati 20 tahun Deklarasi tentang Penghapusan Segala Bentuk Diskriminasi (Yogyakarta: Kanisius, 2010),

Arnold, Thomas Walker. Sejarah Da'wah Islam Terj., (Jakarta: tp, 1979).

Arikunto, Suharsimi , Prosedur

Penelitian Ilmiah, Suatu Pendekatan

Praktek. , (Ed. II; Cet. IX; Jakarta:

Rineka Cipta, 1993),

Assagaf, Ja'far. Hubungan Muslim

Dengan Non Muslim Dalam

Perspektif Hadis, Sinopsis

Disertasi. Sekolah Pascasarjana

Universitas Islam Negeri (UIN)

Syarif Hidayatullah Jakarta 2008 $\mathrm{M} / 1429 \mathrm{H}$.

Anshari, M., H. Endang Saifuddin, Piagam Jakarta 22 Juni 1945 dan

Sejarah Konsensus Nasional

Antara Nasionalis Islami dan Nasionalis "Sekular" Tentang Dasar Negara Republik Indonesia 1945-1959, cet. I, Bandung: Pustaka Perpustakaan Salman ITB, 1401 H/1981.

Azra, Azyumardi. Pendidikan IslamTradisi dan Modernisasi di Tengah Tantangan Milenium III, Cetakan ke - 1 (Jakarta: Kencana, 2012).

Budhi Munawar Rahman (et.all), Bayang-bayang Fanatisisme, Jakarta: Paramadina, 2007

Djamal, Murni. Kesetaraan Hak-Hak Non Muslim Dalam Perspektif AlQuran dan Hadis. (Jakarta: Diterbitkan atas kerjasama PBB UIN dan KAS-Konrad Adenaur Stiftung, 2003).

Departemen Agama RI, Al-Quran dan Terjemahanya, Hadiah dari
Khadim al-Haramain al-Syarifain (pelayan kedua tanah suci) Raja Fahd ibn "Abd al-'Aziz al-Sa'ud, 1413 H. h. 847.

Departemen Pendidikan dan Kebudayaan RI, Kamus Besar Bahasa Indonesia (Jakarta: Balai Pustaka, 1998).

Damami, Mohammad. Kepercayaan terhadap Tuhan Yang Maha Esa Pada Periode 1973-1983: Sebuah Sumbangan Pemahaman Tentang Proses Legalisasi Konstitusional dalam Konteks Pluralitas Keberagamaan di Indonesia. Seri Disertasi, Cetakan Pertama (Jakarta: Kementerian Agama RI, 2011)

Dokumen Yayasan Al-Azhar Mandiri Palu tahun 1985.

Evans,Donna. Kamus Kaili-Ledo Indonesia Inggris, Proyek Pemda Provinsi Sulawesi Tengah, Dinas Kebudayaan dan Pariwisata, Edisi Perdana Jakarta: Sehati Prima Sejahtera, 2003.

Evita, E., Syahid, A., \& Nurdin, N. (2019). Understanding Students' Learning Outcomes Differences Through the Application of the Market Place Activity Type of Cooperative Learning Model and the Application of Conventional Learning Models International Journal of Contemporary Islamic Education, 1(1), 67-85.

Fathi, Mohamed Osman, The Children of Adam an Islamic Perspective on Pluralism, (Washington D.C. : Center For Muslim - Christian Understanding, 1996), h. 2, yang

e-ISSN: $2715-4572$ p-ISSN: 2716-1439 
dikutip oleh Karlina Helmanita, Pluralisme dan Inklusivisme Islam di Indonesia: Kearah Dialog Lintas Agama (Jakarta: Diterbitkan atas kerjasama PBB UIN dan KASKonrad Adenaur Stiftung, 2003)

Hayat, Bahrul. Mengelola Kemajemukan Umat Beragama, Cetakan Pertama, (Jakarta: PT. Saadah Cipta Mandiri, 2012).

Harmoni- Faham Keagamaan Antara Harmoni Dan Konflik- Jurnal Multikultural \& Multireligius: Akreditasi LIPI Nomor : 90/AKRED-LIPI/P2MBI/5/2007, ISSN1412-663X. Volume IX. Nomor 33, Januari -Maret 2010. (Jakarta: Puslitbang Kehidupan Keagamaan Badan Litbang dan Diklat Kementerian Agama RI).

Kearifan Lokal Sebagai Landasan Pembangunan BangsaVolume IX. Nomor 34, April - Juni 2010. (Jakarta: Puslitbang Kehidupan Keagamaan Badan Litbang dan Diklat Kementerian Agama RI).

, Hubungan Antarumat- Dan Kebebasan Beragama- Volume IX. Nomor 36, Oktober - Desember 2010. (Jakarta: Puslitbang Kehidupan Keagamaan Badan Litbang dan Diklat Kementerian Agama RI).

Helmanita, Karlina, Pluralisme dan Inklusivisme Islam di Indonesia ke Arah Dialog Lintas Agama (Jakarta: Diterbitkan atas kerjasama PBB UIN dan KAS-Konrad Adenaur Stiftung, 2003)
Jamal, Murni. Kesetaraan Hak-Hak Non Muslim dalam Perspektif Al-Quran dan Hadis, Jakarta: Diterbitkan atas kerjasama PBB UIN dan KASKonrad Adenauer Stiftung, 2003.

J.P. Chaplin, Kamus Lengkap Psikologi, diterjemahkan oleh Kartini Kartono, dari buku aslinya Dictionary of Psychology Cetakan ke- 15 ( Jakarta: PT.Raja Grafindo Persada, 2011).

John Rex, "the Concept of multicultural society", dalam Monseratt Guibernau and John Rex, The Ethnicity Reader: Nationalism, Multiculturalism and migration (Cambridge, 2010, Polity Press), h. 219 dalam Bahrul Hayat, Mengelola Kemajemukan Umat Beragama, Cetakan Pertama, (Jakarta: PT. Saadah Cipta Mandiri, 2012)

Jumat, Gani. Nasionalisme Ulama Pemikiran Politik Kebangsaan Sayyid Idrus bin Salim Al-Jufri, 1891-1969. Cetakan Pertama, (Jakarta: Kementerian Agama RI, 2012).

Karlina Helmanita, Pluralisme dan Inklusivisme Islam di Indonesia: Kearah Dialog Lintas Agama (Jakarta: Diterbitkan atas kerjasama PBB UIN dan KAS-Konrad Adenaur Stiftung, 2003).

Kruyt, J. Kabar Keselamatan di PosoSejarah Gereja Kristen Sulawesi Tengah Sampai th. 1947. Terjemahan P.S. Naipospos dengan bantuan Dr.Th.v.d.End, Kwitang Jakarta: BPK Gunung Mulia, 1977.

Kurniati, Kurniati, Nurdin, Nurdin, \& Nurasmawati, Nurasmawati. (2020). Improving Students' Cognitive and Affective Domains e-ISSN: 2715-4572 p-ISSN: 2716-1439 
Students through Fostering Teacher Development International Journal of Contemporary Islamic Education, 2(2), 56-70.

L.Midu, Nasrudin. Konsep Manajemen Sayyid Idrus Bin Salim Aljufri Terhadap Modernisasi Pendidikan Islam Alkhairaat, (Disertasi tidak diterbitkan. PPS UIN Alauddin Makassar, 2010).

Mas'ud, Abdurrahman. Dari Haramaian Ke Nusantara: Jejak Intelektual Arsitek Pesantren, Cet. I (Jakarta: Kencana, 2006).

Ma'arif, Ahmad Syafi'i. Sekapur Sirih, dalam W.Cole Durham Jr., Bahia G. Tahzib-Lie, (Editor). Facilitating Freedom of Religion or Believe: A Deskbook, Tore Lindholm,

Madjid, Nurcholish. Islam Doktrin dan Peradaban, (jakarta: Yayasan Wakaf Paramadina, 2000).

Maarif, Ahmad Syafii. Islam dalam Bingkai Keindonesiaan dan Kemanusiaan: Sebuah Refleksi Sejarah, cet. I, Bandung: Mizan, 2009.

Miles, Matthew B. dan A. Michael Huberman, Analisis Data Kualitatif, Buku Tentang Metode-Metode Baru, (Cet. I; Jakarta: UI-Press, 1992), Nainggolan, Nurhayati. (et.al), Sejarah Pendidikan Daerah Sulawesi Tengah. Proyek Penelitian dan Pencatatan Kebudayaan Daerah, Palu: Dep P\&K, 1986/1987.

Nurdin, Nurdin, Stockdale, Rosemary, \& Scheepers, Helana. (2014a). Coordination and Cooperation in E-Government: An Indonesian Local E-Government Case The Electronic Journal of Information
Systems in developing Countries, 61(3), 1-21.

Nurdin, Nurdin. (2018). Institutional Arrangements in E-Government Implementation and Use: A Case Study From Indonesian Local Government. International Journal of Electronic Government Research (IJEGR), 14(2), 44-63. doi: 10.4018/ijegr.2018040104

.Nurdin, Nurdin, Stockdale, Rosemary, \& Scheepers, Helana. (2014b, 6-9 Jan. 2014). The Role of Social Actors in the Sustainability of E-Government Implementation and Use: Experience from Indonesian Regencies. Paper presented at the System Sciences (HICSS), 2014 47th Hawaii International Conference on System Science.

Nurdin, Nurdin, \& Aratusa, Zana Chobita. (2020). Benchmarking level interactivity of Indonesia government university websites. TELKOMNIKA Telecommunication, Computing, Electronics and Control, 18(2), 853-859.

Rahman, Budhi Munawar (et.all), Bayang-bayang Fanatisisme ( Jakarta: Paramadina, 2009).

Soedjatmoko, Etika Pembebasan, Pilihan Karangan tentang: Agama, Kebudayaan, Sejarah dan Ilmu Pengetahuan. cet. III, Jakarta: LP3ES, 1988.

Shihab, Alwi. Islam Inklusif Menuju Sikap Terbuka Dalam Beragama, cet. IV, Bandung: Diterbitkan atas Kerja Sama Anteve-Mizan, 1998. 
Subagyo, P joko, Metode Penelitia Dalam Teori Dan Praktek, (Cet. II; Jakarta: PT Rineka Cipta, 1997)

Soekanto, Soerjono. Kamus Sosiologi, Cetakan ketiga (Jakarta: PT.Raja Grafindo, 1993).

Osman, Mohamed Fathi. The Children of Adam an Islamic Perspective on Pluralism, dalam (Washington D.C. : Center For Muslim Christian Understanding, 1996).

T. Yanggo, Huzaemah dan Gani Jumat, (at.al). Sayyid Idrus Bin Salim Aljufri Pendiri Alkhairaat Dan Kontribusinya Dalam Pembinaan Umat. (Cetakan: Pertama. Jakarta: Gaung Persada, 2013).

Thomas Walker Arnold, Sejarah Da'wah Islam Terj., (Jakarta: tp, 1979), h. 5152 dalam Murni Djamal, Kesetaraan Hak-Hak Non Muslim Dalam Perspektif Al-Quran dan Hadis. (Jakarta: Diterbitkan atas kerjasama PBB UIN dan KASKonrad Adenaur Stiftung, 2003)

Truna, Dodi S. Pendidikan Agama Islam Berwawasan Multikulturalisme, Telaah Kritis atas muatan Pendidikan Multikulturalisme dalam Buku Ajar Pendidikan Agama Islam (PAI) di Perguruan Tinggi Umum di Indonesia. Seri Disertasi, Cetakan Pertama (Jakarta: Kementerian Agama RI, 2010).

Willya, Evra. Hubungan Antar Umat Beragama Menurut Thabathaba'i Dalam Tafsir Al-Mizan. Sinopsis Disertasi. Sekolah Pascasarjana Universitas Islam Negeri (UIN)
Syarif Hidayatullah Jakarta 2008 M/1429 H. 